\title{
STUDI FORMULASI RUMPUT LAUT (Kappaphycus alvarezii) DAN TEPUNG SAGU (Metroxylon sp.) TERHADAP KOMPOSISI KIMIA, STABILITAS DAN SIFAT SENSORI PADA PRODUK CENDOL RUMPUT LAUT
}

\author{
Selin Lolopayung *, Asnani, Kobajashi T. Ishamu \\ Jurusan Teknologi Hasil Perikanan Fakultas Perikanan dan Ilmu Kelautan Universitas Halu Oleo, \\ Jalan H.E.A Mokodompit Kampus Bumi Tridharma Anduonohu, Kendari 93232 Sulawesi Tenggara \\ Telepon +6282188916185 \\ *Korespondensi: selinlolopayung96@gmail.com \\ Diterima: 7 Maret 2019/Disetujui: 26 Maret 2019
}

Cara sitasi: Lolopayung S, Asnani, Ishamu KT. 2019. Studi formulasi rumput laut (Kappaphycus alvarezii) dan tepung sagu (Metroxylon sp.) terhadap komposisi kimia, stabilitas dan sifat sensori pada produk cendol rumput laut. Jurnal Fish Protech. 2(1):1-10.

\begin{abstract}
Abstrak
Penelitian ini bertujuan untuk mengetahui pengaruh perbandingan bubur rumput laut dan tepung sagu terhadap kandungan kimia, sensori dan stabilitas cendol rumput laut, metode penelitan ini menggunakan rancangan acak lengkap (RAL) dan uji Kruskal Wallis yang terdiri dari 3 perlakuan yaitu dengan variasi penambahan konsentrasi rumput laut $(\mathrm{R})$ dan tepung sagu (S) yang berbeda dimana perlakuan $\mathrm{RS} 1$ ( $\mathrm{R}=30 \%$ : $\mathrm{S}=70 \%)$, RS2 ( $\mathrm{R}=20 \%: \mathrm{S}=80 \%)$ dan $\mathrm{RS} 3(\mathrm{R}=10 \%: \mathrm{S}=90 \%)$. Kandungan air, abu dan serat diuji menggunakan metode Gravimetri, kandungan karbohidrat Spektrofotometri, uji stabilitas menggunakan metode Saade dan Aslamyah dan uji sensori menggunakan metode Kruskal Wallis (SPSS 16.0). Hasil uji kandungan air, abu dan serat tertinggi terdapat pada perlakuan RS1 dengan nilai 85,50; 0,12 dan 1,76\%. Kandungan karbohidrat tertinggi terdapat pada perlakuan RS3 dengan nilai 16,08\% dan hasil nilai stabilitas tertinggi terdapat pada perlakuan RS3 dengan waktu 275 menit. Hasil penelitian ini menunjukkan bahwa tidak terdapat pengaruh pada kandungan kimia air, abu, serat dan uji stabilitas, sedangkan kandungan karbohidrat terdapat penggaruh nyata yang ada pada cendol rumput laut pada setiap perlakuan.
\end{abstract}

Kata kunci : Cendol, rumput laut, tepung sagu, komposisi kimia, uji sensori

\section{STUDY OF SEAWEED PULP (Kappaphycus alvarezii) And Sagu Flour (Metroxylon sp.) FORMULATIONS ON CHEMICAL COMPOSITION, STABILITY AND SENSORY PROPERTIES OF SEAWEED CENDOL PRODUCTS}

\begin{abstract}
This study aims to determine the effect of the comparison of seaweed and sagu flour on the chemical, sensory and stability content of seaweed cendol, this research method uses a completely randomized design (CDR) and non-parametric (Kruskal Wallis) consisting of 3 treatments with additional variations Different concentrations of seaweed $(\mathrm{R})$ and sagu flour (S) where RS1 (R=30\%: $\mathrm{S}=70 \%), \mathrm{RS} 2(\mathrm{R}=20 \%: \mathrm{S}=80 \%)$ and $\mathrm{RS} 3(\mathrm{R}=10 \%$ :
\end{abstract}


$\mathrm{S}=90 \%$ ). Water, ash and fiber content were tested by the Gravimetric method, carbohydrate content was tested by the spectrophotometric, stability test tested by Saade and Aslamyah methods and sensory tests by the Kruskal Wallis method (SPSS 16.0). The higher test results of water, ash and fiber content were found in the treatment of RS1 with a value of $85.50 ; 0.12$ and $1.76 \%$, the higher carbohydrate content was found in the RS3 treatment with a value of $16.08 \%$ and the higher stability test results were found on RS3 treatment with 275 minutes. The study indicate that there is no effect on the chemical content of water, ash, fiber and stability test, and the carbohydrate content of the significant effect is present in seaweed cendol in each treatment.

Key words: Cendol, seaweed, sagu flour, chemical composition, sensory test

\section{PENDAHULUAN}

Rumput laut merupakan salah satu komoditas unggulan perikanan budidaya yang produksinya tersebar diantara komoditas unggulan lainnya (Anonim, 2016). Budidaya rumput laut telah berkembang pada setiap Kabupaten atau Kota, se-Provinsi Sulawesi Tenggara. Potensi untuk pengembangan budidaya rumput laut sebesar 230.170 ha yang diperkirakan dapat memproduksi rumput laut sebanyak 262.073,5 ton/tahun, luas pengembangan paling potensial berada di Kabupaten Buton dan paling sempit di Kota Kendari (Anonim, 2015).

Rumput laut jenis (Kappaphycus alvarezii) merupakan salah satu sumberdaya alam hayati Indonesia yang mempunyai nilai ekonomis yang penting dalam industri kosmetik, pangan dan lain-lain,yang banyak diolah dalam bentuk kering setelah melalui proses penjemuran atau diolah menjadi makanan siap konsumsi, seperti dodol, manisan dan minuman (Nursanto, 2004). Rumput laut merupakan salah satu bahan dasar yang dapat menghasilkan agar, karagenan dan alginat, $K$. alvarezii merupakan rumput laut penghasil kargenan. Rumput laut sering kali ditambahkan pada produk makanan sebagai alternatif bahan yang menguntungkan dan dapat meningkatkan nilai gizi. Rumput laut bermanfaat untuk kesehatan karena kandungan zat gizinya antara lain karbohidrat, protein, mineral, vitamin dan sedikit lemak, lebih banyak vitamin A (beta karoten), B1, B2, B6, B12, C dan niacin, serta mineral yang penting seperti kalsium dan zat besi (Nursanto, 2004). Kandungan serat (diatery fiber) pada rumput laut bersifat untuk mengenyangkan dan memperlancar proses metabolisme tubuh. Rumput laut yang digunakan pada pembuatan cendol berupa bubur rumput laut. Bubur rumput laut (BRL) merupakan hasil olahan dari rumput laut yang telah dihaluskan secara mekanis dengan menggunakan mesin penghalus (blender) sehingga memudahkan dalam proses pembuatan adonan cendol rumput laut (Ubaedillah, 2008). Pembuatan cendol selain menggunakan rumput laut juga menggunakan tepung sagu sebagai bahan pendukung.

Sagu merupakan komoditas andalan yang dapat digunakan sebagai sumber karbohidrat potensial, terutama untuk Kawasan Timur Indonesia. Pengembangan dan pemanfaatan sagu sangat strategis untuk menunjang dan menjamin ketersediaan pangan. Selain dimanfaatkan sebagai bahan pangan alternatif, dalam bentuk pangan pokok seperti sinonggi, kapurung atau papeda dan sebagai pangan pendamping dalam 
bentuk sagu lempeng, sinali, bagea, sagu dapat pula dimanfaatkan atau diolah menjadi cendol.

Cendol merupakan salah satu produk pangan (minuman) yang banyak digemari masyarakat. Cendol dapat terbuat dari tepung beras dengan campuran tepung tapioka, agar dan tepung hunkwee. Adonan campuran tepung dibentuk menjadi bulir yang diminum dengan campuran santan dan gula atau sirup.Cendol merupakan makanan yang mempunyai ciri khas yang berwarna hijau dengan bentuk memanjang (Rahman dan Hermiza, 2015).

Berdasarkan latar belakang diatas, maka dilakukan penelitian yang berjudul uji komposisi kimia, stabilitas dan sifat sensori cendol rumput laut dengan perbandingan bubur rumput laut dan tepung sagu yang berbeda.

\section{BAHAN DAN METODE}

\section{Bahan dan Alat}

Bahan yang digunakan yaitu rumput laut dan tepung sagu. Bahan utama adalah bubur rumput laut dan bahan pendukung adalah tepung sagu, serta bahan tambahan yaitu air dan perisa pandan. Bahan untuk analisis proksimat adalah aquades, $\mathrm{NaOH}$ dan kertas saring, $\mathrm{H}_{2} \mathrm{SO}_{4}$ dan alkohol, fenol, asam sulfat pekat, glukosa.

Alat yang digunakan dalam penelitian ini teridiri antara lain, blender, ayakan, sendok kayu, cetakan cendol, baskom, panci, dan kompor. Sedangkan peralatan untuk melakukan analisis kimia adalah cawan petri (pyrex), oven (memmert), desikator (equipment pharmacy), tanur (alabtech), cawan porselen (RRC), kompor listrik, gelas piala (iwaki pyrex), corong buncher (pyrex), labu penghisap (pyrex), gelas ukur (pyrex), gegep, Spektrofotometer.

\section{Rancangan Penelitian}

Penelitian ini menggunakan Rancangan Acak Lengkap (RAL) yang terdiri dari 3 perlakuan yaitu RS1 (bubur rumput laut 30\% : tepung sagu $70 \%$ ), RS2 (bubur rumput laut 20\%: tepung sagu 80\%) dan RS3 (bubur rumput laut 10\%: tepung sagu 90\%) diulang sebanyak 3 kali sehingga diperoleh 9 unit percobaan.

\section{Penyedian Bahan Baku}

Bahan yang digunakan yaitu rumput laut dan tepung sagu. Rumput laut diambil dalam bentuk kering di Desa Tanjung Tiram, Kecamatan Moramo, Kabupaten Konawe Selatan, di mana penanganan rumput laut kering meliputi beberapa proses yaitu rumput laut kering direndam selama 2 hari menggunakan air cucian beras dan setiap 12 jam air diganti, kemudian rumput laut yang telah direndam ditiriskan \pm 5 menit (berdasarkan metode Ubaedillah, 2008).Sedangkan pada tepung sagu meliputi, sagu segar yang diambil di Pasar Tanea, Kecamatan Konda, Kabupaten Konawe Selatan terlebih dahulu dilarutkan didalam air dan kemudian disaring untuk memisahkan kotoran, kemudian di rendam \pm 2 hari, dan setiap 12 jam air harus diganti, lalu air rendaman dibuang setelah itu sagu di jemur di bawah sinar matahari \pm 2 hari/sampai kering (Mulyo, 2016).

\section{Pembuatan Bubur Rumput Laut dan Tepung Sagu}

Proses pembuatan bubur rumput laut meliputi, rumput laut yang telah direndam dan tidak berbau amis kemudian dilakukan pengecilan ukuran dengan cara di blender yang bertujuan untuk menghaluskan rumput laut hingga menjadi bubur. Proses pembuatan tepung sagu yaitu sagu yang telah kering kemudian diayak dengan 
menggunakan pengayak 80 mesh untuk mendapatkan tepung sagu.

\section{Pembuatan dan Formulasi Bulir Cendol}

Pembuatan bulir cendol dimulai dengan mencampurkan bubur rumput laut dan tepung sagu sesuai dengan perlakuan dan ditambahkan airsebanyak $50 \mathrm{ml}$ dan juga perisa pandan sebanyak $5 \mathrm{ml}$, lalu diuleni sampai semi basa (sampai biasa dicetak). Adonan yang telah dicampur kemudian dicetak menggunakan cetakan cendol dan direbus pada air yang telah mendidih dengan suhu $100{ }^{\circ} \mathrm{C}$ selama 2 menit. Cendol yang sudah matang lalu ditiriskan dan diletakkan pada wadah yang berisi air es dengan suhu $5^{\circ} \mathrm{C}$.

\section{Parameter Uji (Sensori, Proksimat dan Stabilitas)}

Cara menentukan cendol rumput laut yang paling disukai oleh panelis dari setiap perlakuan, dilakukan penilaian sensori terhadap produk cendol rumput laut yang meliputi kenampakan, aroma, tekstur dan rasa dengan menggunakan skala sensori. Pengujian menggunakan 20 orang panelis.

Analisis kadar air metode gravimetri berdasarkan Official Method AOAC (2005), kadar abu AOAC (2005), kadar karbohidrat total (Fenolasam Sulfat/Spektrofotometri) (Anonim, 2005) dan analisis kadar serat menggunakan metode Gravimetri (Sudjana, 1986).

Uji kecepatan pecah mengukur berapa lama waktu sampai bulir cendol hancur di dalam air. Uji inidiamati secara visual. Sebanyak 10 bulir cendol dimasukkan ke dalam beaker glass yang diisi $1 \mathrm{~L}$ air, untuk mengetahui bulir cendol sudah lembek atau belum dilakukan penekanan dengan jari telunjuk. Pengamatan ini dilakukan dengan memencet bulir cendol setiap lima menit (Saade dan Aslamyah, 2009 dengan modifikasi).

\section{Analisis Data}

Penelitian ini menggunakan Rancangan Acak Lengkap (RAL) yang terdiri dari 3 perlakuan yaitu penambahan kombinasi bubur rumput laut dan tepung sagu masing-masing 30\%:70\%, 20\%:80\% dan 10\%:90\%. Masing-masing perlakuan dilakukan tiga kali ulangan, sehingga diperoleh jumlah satuan percobaan sebanyak 9 unit.

Untuk mengetahui pengaruh perlakuan terhadap uji komposisi proksimat (kadar air, kadar abu, kadar karbohidrat dan kadar serat yang akan diamati maka akan dilakukan analisis ragam (ANOVA) dan jika terdapat pengaruh nyata pada perlakuan yang diberikan maka akan dilanjutkan dengan uji DMRT pada tingkat kepercayaan 95\% $(\alpha=0,05)$ (Steel and Torrie, 1993).

Analisis data sensori dalam penelitian ini menggunakan analisis statistik non parametrik metode Krusskal wallis dengan menggunakan SPSS 16.0 untuk mengetahui adanya pengaruh yang signifikan pada masingmasing perlakuan terhadap kualitas sensorik cendol rumput laut. Apabila terdapat pengaruh yang signifikan, maka dilakukan uji lanjut MannWhitney $U$ Test untuk mengetahui pengaruh antar perlakuan dengan taraf kepercayaan $95 \%(\alpha=0.05)$.

\section{HASIL DAN PEMBAHASAN}

\section{Analisis Kimia Cendol Rumput Laut}

Berdasarkan analisis kimia CRL sampai penambahan bubur rumput laut $30 \%$ didapatkan nilai tertinggi kadar air, abu dan serat terdapat pada perlakuan RS1 yaitu 85,50\%; $0,12 \%$ dan $1,76 \%$ 
sedangkan pada karbohidrat terdapat pada perlakuan RS3 yaitu $16,08 \%$. Analisis ragam terhadap nilai kadar air, abu dan serat cendol rumput laut menunjukkan bahwa perlakuan yang diberikan berpengaruh tidak nyata sehingga tidak dilanjutkan dengan uji
Duncan Multiple Range Test (DMRT) pada taraf 95\% $(\alpha: 0,05)$. Sedangkan kadar karbohidrat berpengaruh nyata sehingga dilanjutkan dengan uji Duncan Multiple Range Test (DMRT) pada taraf $95 \%(\alpha: 0,05)$. Hasil analisis kimia dapat dilihat pada Tabel 1.

Tabel 1. Hasil analisis kimia cendol rumput laut

\begin{tabular}{|c|c|c|c|c|}
\hline \multirow{2}{*}{ No } & \multirow{2}{*}{ Parameter } & \multicolumn{3}{|c|}{ Sampel } \\
\hline & & $\mathrm{RS} 1 \pm \mathrm{SD}$ & $\mathrm{RS} 2 \pm \mathrm{SD}$ & $\mathrm{RS} 3 \pm \mathrm{SD}$ \\
\hline 1 & Kadar Air & $85,50 \pm 0,34$ & $85,11 \pm 0,71$ & $85,07 \pm 0,52$ \\
\hline 2 & Kadar Abu & $0,12 \pm 0,05$ & $0,09 \pm 0,01$ & $0,06 \pm 0,02$ \\
\hline 3 & Kadar Karbohidrat & $10,77 \pm^{\mathrm{a}} 1,23$ & $13,85 \pm^{\mathrm{b}} 1,27$ & $16,08 \pm^{\mathrm{c}} 1,31$ \\
\hline & DMRT 0,05 & & $2=0,56$ & $3=0,58$ \\
\hline 4 & Kadar Serat & $1,76 \pm 0,09$ & $1,69 \pm 0,47$ & $1,33 \pm 0,27$ \\
\hline
\end{tabular}

Keterangan: RS1 = Bubur rumput laut 30\%:tepung sagu 70\%; RS2 = bubur rumput laut 20\% : tepung sagu $80 \%$; RS3 = bubur rumput laut $10 \%$ :tepung sagu $90 \%$

Nilai tertinggi kadar air CRL terdapat pada perlakuan RS1 yaitu $85,50 \%$, kadar air pada penelitian ini lebih tinggi dari kadar air tertinggi produk cendol surimi ikan lele dari hasil penelitian (Patmawati, 2011) yaitu $72,34 \%$ dengan penambahan surimi $35 \%$, sedangkan untuk cendol komersial memiliki kadar air yang lebih tinggi yaitu $91,1 \%$. Hal ini diduga karena pada perlakuan RS1 penambahan bubur rumput laut lebih banyak, dimana rumput laut menggandung kadar air yang tinggi sehingga dengan bertambahnya konsentrasi rumput laut akan meningkatkan nilai kadar air pada cendol rumput laut. Menurut (Ubaedillah, 2008) perbedaan kadar air pada cendol rumput laut disebabkan adanya tambahan rumput laut pada masing-masing formula tersebut, dimana bubur rumput lautEucheuma cotoniimemiliki kandungan air yang cukup tinggi yaitu $96,12 \%$ sehingga meningkatkan kadar air cendol tersebut.

Nilai tertinggi kadar abu terdapat pada perlakuan RS1 yaitu $0,12 \%$, kadar abu pada penelitian ini lebih rendah dari kadar abu tertinggi produk cendol surimi ikan lele dari hasil penelitian (Patmawati, 2011) yaitu $0,69 \%$ dengan penambahan surimi $30 \%$, dan untuk cendol komersial memiliki kadar abu yaitu $0,19 \%$. Hal ini diduga karena pada perlakuan RS1 penambahan bubur rumput laut lebih tinggi. Penelitian ini kandungan kadar abu lebih tinggi diduga karena rumput laut yang digunakan memiliki kadar abu yang tinggi. Hal ini didukung oleh Yuliarti (1999) dalam Ubaedillah (2008) menyatakan bahwa penambahan rumput laut pada suatu produk dapat meningkatkan nilai kadar abunya. Semakin banyak rumput laut yang ditambahkan maka kadar abu akan semakin tinggi. Hal ini disebabkan rumput laut memberikan sumbangan zat mineral yang cukup tinggi. Hal ini juga didukung oleh penelitian Lukito et al. (2017) bahwa kadar abu dapat menunjukkan total mineral dalam suatu bahan dimana tepung rumput laut yang memiliki kandungan mineral lebih banyak sehingga dapat menentukan nilai kadar abu pada dodol.

Nilai kandungan karbohidrat tertinggi terdapat pada perlakuan RS3 
yaitu 16,08\%, kadar karbohidrat pada penelitian ini lebih rendah dari kadar karbohidrat tertinggi produk cendol surimi ikan lele dari hasil penelitian (Patmawati, 2011) yaitu 23,71\% dengan penambahan surimi $30 \%$, sedangkan untuk cendol komersial memiliki kadar karbohidrat yang lebih rendah yaitu $6,72 \%$. Hal ini diduga karena penambahan konsentrasi bubur rumput laut lebih sedikit dan tepung sagu dengan konsentrasi lebih banyak, sehingga dengan penambahan tepung sagu yang lebih banyak maka kadar karbohidrat semakin tinggi. Hal ini sesuai dengan penelitian Halim et al. (2015) menyatakan bahwa kandungan karbohidrat akan meningkat seiring dengan bertambahnya persentase pati sagu yang digunakan. Hal tersebut terjadi karena pati sagu memiliki kandungan karbohidrat yang tinggi.

Nilai kandungan serat tertinggi terdapat pada perlakuan RS1 yaiitu $1,76 \%$, kadar serat pada penelitian ini lebih tinggi dari kadar serat tertinggi produk jelly drink rumput laut dari hasil penelitian (Wati dan Ida, 2015) yang sebesar $0,44 \%$. Hal ini diduga karena pada perlakuan RS1 penambahan bubur rumput laut lebih tinggi, dimana rumput laut memiliki kandungan serat yang cukup tinggi. Menurut Lukito et al.(2017), rumput laut Eucheuma cottonii sebagai penghasil karaginan mempunyai kandungan serat yang tinggi. Berbeda dengan penelitian yang dilakukan oleh Astawan et al. (2004) bahwa kadar serat dodol rumput laut mempunyai nilai yang lebih tinggi yaitu 6,20\%, dibandingkan dengana perlakuan RS1. Hal ini disebabkan tingginya kadar serat pada dodol rumput laut disebabkan pada formula dodol rumput laut tepung ketan diganti dengan bubur rumput laut yang kadar seratnya lebih tinggi 13,98\% (bb) dibandingkan tepung ketan dengan kadar serat 2,1-5,3\% (bb).

\section{Uji Sensori}

Hasil rerata sensori dengan perlakuan RS1 (30\% bubur rumput laut : $70 \%$ tepung sagu), RS2 (20\% bubur rumput laut : $80 \%$ tepung sagu) dan RS3 (10\% bubur rumput laut : $90 \%$ tepung sagu) produk cendol rumput laut dengan penilaian meliputi kenampakan, aroma, tekstur dan rasa dapat dilihat pada Tabel 2.

Tabel 2. Rerata atribut sensoricendol rumput laut

\begin{tabular}{|c|c|c|c|c|}
\hline \multirow[b]{2}{*}{ No } & \multirow[b]{2}{*}{$\begin{array}{l}\text { Atribut } \\
\text { sensorit }\end{array}$} & \multicolumn{3}{|c|}{ Perlakuan } \\
\hline & & RS1 & RS2 & RS3 \\
\hline 1 & Kenampakan & $\begin{array}{r}\text { 3,9 ( utuh, cerah, } \\
\text { khas cendol) }\end{array}$ & $\begin{array}{l}\text { 3,1 (utuh, kurang } \\
\text { cerah, khas } \\
\text { cendol) }\end{array}$ & $\begin{array}{c}\text { 2,3 (kurang utuh, } \\
\text { kurang cerah, } \\
\text { khas cendol) }\end{array}$ \\
\hline 2 & Aroma & $\begin{array}{l}\text { 3,9 } \text { (bau amis } \\
\text { rumput laut } \\
\text { sedikit) }\end{array}$ & $\begin{array}{l}3,9 \text { (bau amis } \\
\text { rumput laut } \\
\text { sedikit) }\end{array}$ & $\begin{array}{l}\text { 3,7 } \text { (bau amis } \\
\text { rumput laut } \\
\text { sedikit) }\end{array}$ \\
\hline 3 & Tekstur & 3,7 (kenyal) & 3,9 (kenyal) & 3,8 (kenyal) \\
\hline 4 & Rasa & $\begin{array}{c}\text { 4,0 (enak, spesifik } \\
\text { rasa cendol } \\
\text { rumput laut) }\end{array}$ & $\begin{array}{l}\text { 3,9 (enak, spesifik } \\
\text { rasa cendol } \\
\text { rumput laut) }\end{array}$ & 3,5 (netral) \\
\hline
\end{tabular}


Berdasarkan analisis Krusskal Wallis yang dilakukan penambahan bubur rumput laut dan tepung sagu pada setiap konsentrasi dalam pembuatan cendol rumput laut menunjukan perbedaan yang signifikan terhadap nilai rata-rata kenampakan cendol rumput laut. Hasil uji lanjut Mann Whitney $U$ Test menunjukan perlakuan cendol rumput laut dengan penambahan rumput laut dan tepung sagu RS1 (R 30\% : S 70\%), perlakuan RS2 (R 20\% : S 80\%) dan RS3 (R 10\% : S $90 \%$ ) ada perbedaan yang signifikan. Perlakuan RS3 memiliki kenampakan yang rendah dibandingkan perlakuan RS1 dan RS2. Warna yang dihasilkan pada setiap perlakuan berbeda-beda, hal ini diduga karena presentase penambahan tepung sagu dalam jumlah yang cukup banyak, sehingga memperlihatkan perbedaan kenampakan pada masing-masing produk cendol yang dibuat. Hal ini didukung oleh Yuwono dan Susanto (1998) yang menyatakan bahwa proporsi bahan pembentuk gel yang semakin besar menyebabkan makin banyak cairan yang terperangkap dalam gel dan ikatan antara pembentuk gel dengan cairan lebih rapat yang menyebabkan warna menjadi lebih gelap.

Hasil perhitungan reratasensori aroma berdasarkan analisa Krusskal Wallis yang dilakukan bahwa perbedaan penambahan bubur rumput laut dan tepung sagu pada semua perlakuan tidak menunjukkan perbedaan yang signifikan. Perlakuan RS3 memiliki aroma yang rendah dibandingkan dengan perlakuan RS1 dan RS2. Hal ini diduga presentase penambahan rumput laut yang digunakan dalam jumlah sedikit, dimana aroma khas rumput laut tidak berpengaruh secara signifikan disebabkan pada proses sebelum pengolahan yaitu tahap perendaman rumput laut menggunakan air cucian beras. Air cucian beras ini berfungsi untuk menghilangkan bau amis rumput laut sehingga dengan banyaknya penambahan tepung sagu yang digunakan akan menutupi aroma khas rumput laut pada produk cendol yang dibuat. Menurut Chaidir (2007), tepung beras dengan kandungan pati yang tinggi dapat menghilangkan bau amis pada rumput laut. Syamsuddin et al. (2015) menyatakan bahwa selama pemasakan akan terjadi berbagai reaksi antara bahan pengisi dan bahan utama rumput laut, sehingga aroma yang khas pada rumput laut akan berkurang selama pengolahan produk.

Hasil perhitungan rerata sensori tekstur berdasarkan analisa Krusskal Wallis yang dilakukan bahwa perbedaan penambahan bubur rumput laut dan tepung sagu pada semua perlakuan tidak menunjukan perbedaan yang signifikan. Perlakuan RS1 memiliki tekstur yang rendah dibandingkan dengan perlakuan RS2 dan RS3. Hal ini diduga karena pada setiap sampel yang diformulasi presentase tepung sagu lebih banyak. Perbedaan kekenyalan tersebut dipengaruhi oleh perbedaan sifat antara rumput laut dengan tepung sagu, pati sagu dalam penelitian ini memiliki kadar amilosa lebih besar yang memungkinkan terbentuknya gel yang lebih kokoh. Menurut Blennow (2004), menyatakan bahwa pati dengan kadar amilosa tinggi cocok untuk produkproduk yang bertekstur kenyal seperti puding dan cendol disebabkan besarnya kemampuan pati untuk membentuk gel menjadi kokoh. Ubaedillah (2008) menambahkan bahwa tekstur cendol rumput laut dipengaruhi oleh komposisi tepung yang digunakan dalam pembuatan adonan.

Hasil uji lanjut Mann Whitney $U$ Test menunjukan perlakuan cendol rumput laut dengan penambahan rumput laut dan tepung sagu RS1 
(R 30\% : S 70\%) dan perlakuan RS2 (R $20 \%$ : S $80 \%$ ) tidak ada perbedaan yang signifikan, sedangkan pada perlakuan RS3 (R 10\% : S 90\%) menunjukan perbedaan nyata. Perlakuan RS3 memiliki rasa yang rendah dibandingkan dengan perlakuan RS1 dan RS2. Hal ini diduga karena presentase penambahan tepung sagu yang semakin banyak dan rumput laut semakin sedikit sehingga diduga rasa dari rumput laut tertutupi oleh rasa sagu yang membuat rasa dari rumput laut tidak terlalu kuat. Cendol dalam penelitian disajikan dalam bentuk es dawet, yakni dengan tambahan kuah santan, gula jawa, dan es batu. Hal ini sesuai dengan penelitian Dewi et al. (2014) putu ayu dengan presentase $20 \%$ merupakan kudapan yang memiliki rasa paling disukai dibandingan dengan tujuh sampel lain yang diberi perlakuan.
Hal ini disebabkan karena presentase subtitusi tepung rumput laut tidak terlalu banyak sehingga tidak mengubah rasa asli dari kudapan tersebut namun tetap terasa adanya rumput laut dalam kudapan tersebut.

\section{Uji Stabilitas}

Berdasarkan hasil yang didapatkan nilai rerata uji stabilitas CRL sampai penambahan bubur rumput laut 30\% didapatkan nilai paling stabil tertinggi pada perlakuan RS3 yaitu 275 menit. Analisis ragam terhadap nilai stabilitas rumput laut menunjukkan bahwa perlakuan yang diberikan berpengaruh tidak nyata terhadap stabilitas cendol, sehingga tidak dilanjutkan dengan uji Duncan Multiple Range Test (DMRT) pada taraf 95\% $(\alpha: 0,05)$. Rata-rata nilai air dapat dilihat pada Tabel 3.

Tabel 3. Rata-rata nilai stabilitas cendol rumput laut.

\begin{tabular}{cc}
\hline Perlakuan & Rata-rata nilai uji stabilitas (jam) \pm SD \\
\hline RS1 (RS 30:70) & $4,05 \pm 0,42$ \\
RS2 (RS 20 : 80) & $4,30 \pm 0,02$ \\
RS3 (RS 10:90) & $4,35 \pm 0,30$ \\
\hline
\end{tabular}

Keterangan: $\mathrm{R}=$ bubur rumput laut, $\mathrm{S}=$ tepung sagu

Nilai uji stabilitas tertinggi terdapat pada perlakuan RS3 yaitu 275 menit, hal ini diduga pada perlakuan RS3 paling stabil dimana penambahan bubur rumput laut lebih sedikit dan tepung sagu dengan konsentrasi lebih banyak, membuat bulir cendol tidak mudah pecah. Menurut Auliah (2012) tepung sagu apabila dipanaskan lebih kental sehingga menyebabkan penyerapan air lebih lambat.

\section{KESIMPULAN}

1. Perbandingan bubur rumput laut dan tepung sagu pada produk cendol, berpengaruh tidak nyata terhadap uji kimia pada kadar air, kadar abu dan kadar serat dengan nilai tertinggi pada perlakuan RS1 masing-masing $85,5 \%, \quad 0,12 \%$ dan $1,76 \%$ sedangkan pada karbohidrat terdapat pengaruh nyata dengan nilai tertinggi pada perlakuan RS3 16,08\%.

2. Perbandingan bubur rumput laut dan tepung sagu pada produk cendol yang paling disukai oleh panelis yaitu pada perlakuan RS1 (R 30\% : S 70\%).

3. Perbandingan bubur rumput laut dan tepung sagu pada produk cendol, berpengaruh tidak nyata pada uji stabilitas dan yang paling stabil pada perlakuan RS3 yaitu dengan tingkat kestabilan 275 menit. 


\section{DAFTAR PUSTAKA}

AOAC. 2005. Offivall Method Ps of Analysis. 18th ed. Association of Offical Analytical Chemists, Washington DC.

Astawan M, Sutrisno K, Fanie H. 2004. Pemanfaatan Rumput Laut (Eucheuma cottonii) untuk Meningkatkan Kadar Iodium dan Serat Pangan pada Selai dan Dodol.Vol. XV Nomor 1 . Teknologi dan Industri Pangan. IPB Bogor.

Auliah A, 2012. Formulasi Kombinasi Tepung Sagu dan Jagung pada Pembuatan Mie. [Jurnal]. Vol. 13 Nomor 2.

Anonimous. 2005. Petunjuk Teknis Analisis Kimia Tanah, Tanaman, Air dan Pupuk. Balai Penelitian Tanah. Badan Penelitan Dan Pengembangan Pertanian. Departemen Pertanian.

Anonimous. 2015. Potensi Rumput Laut. Kondisi usaha rumput laut di Provinsi Sulawesi Tenggara. Bank Indonesia Sultra.4 hal.

Blennow A. 2004. Starch bioenginerring. Dalam: Elliason, A.C. Starch in Food. Structure, Function and Application. Woodhead Publishing Limited, Cambridge.

Chaidir A. 2007. Kajian Rumput Laut Sebagai Sumber Serat Alternatif untuk Minuman Berserat [Tesis] Bogor : Sekolah Pasca Sarjana, Institut Pertanian Bogor.

Dewi AP, Mardiana, Irwan B. 2014. Pemanfaatan Rumput Laut untuk Meningkatkan Kandungan Iodium Pada Makanan Tambahan Balita. [Jurnal]
Universitas Negeri Semarang, Indonesia.

Halim, Akhyar A, Rahmayuni. 2015. Evaluasi Mutu Roti Manis Dari Tepung Komposit (Tepung Terigu, Pati Sagu, Tepung Tempe). [Jurnal] Vol. 07, No. 02. Jurusan Teknologi Hasil Pertanian, Universitas Syiah Kuala.

Anonimous. 2016. Laporan Kinerja Kementerian Kelautan dan Perikanan Tahun 2015. Tersedia pada :http://kkp.go.id/assets/uplo ads/2016/07/Buku-LKJK 2015. [11 Juli 2016].

Lukito MS, Giyarto, Jayus. 2017. Sifat Fisik, Kimia dan Organoleptik Dodol Hasil Variasi Rasio Tomat Dan Tepung Rumput Laut. [Jurnal] Vol. 11 No. 01. Fakultas Teknologi Pertanian, Universitas Jember.

Mulyo BW. 2016. Kajian Pengolahan Pati Sagu (Metroxylon sago) Terhadap Daya Cerna Pati, Kadar Pati dan Air Pada Olahannya [Skripsi]. Semarang. Fakultas Teknologi Pertanian. Universitas Semarang.

Nursanto I. 2004. Pembuatan Minuman Sebagai Usaha Diversifikasi Rumput Laut Eucheuma cottoni [Skripsi]. Bogor. Fakultas Perikanan dan Ilmu Kelautan Institut Pertanian Bogor.

Patmawati. 2011. Pengembangan Dessert Berbasis Isolat Protein Basah Ikan Lele (Clarias sp.) dengan Pewarna Alami [Skripsi]. Bogor. Fakultas Perikanan Dan Ilmu Kelautan Institut Pertanian Bogor. 
Rahman M, Hermiza M. 2015. Yuwono SS, Susanto T. 1998. Pengaruh Perbandingan Tepung Beras Dan Tepung Tapioka Terhadap Penerimaan Konsumen pada Cendol. [Jurnal] Vol.4, No. 1.

Saade E, Aslamyah S. 2009. Uji fisik dan kimiawi pakan buatan untuk udang windu penaeus monodon fab. yang menggunakan berbagai jenis rumput laut sebagai bahan perekat. J. Ilmu Kelautan dan Perikanan. 19(2): 107-115.

Steel RGD, Torrie JH. 1993. Prinsip dan Prosedur Statistika. Jakarta: Penerbit PT. Gramedia Pustaka Utama.

Sudjana S. 1986. Penuntun Praktikum Analisis Zat Gizi. IPB, Bogor

Syamsuddin N, Lahming, Muhammad WC. 2015. Analisis Kesukaan Terhadap Karakteristik Olahan Nugget yangDisubtitusi dengan Rumput Laut dan Tepung Sagu. [Jurnal] Vol. 1.Pendidikan Teknologi Pertanian.

Ubaedillah. 2008. Kajian Rumput Laut Eucheuma cottonii Sebagai Sumber Serat Alternatif Minuman Cendol Instan [Seripsi]. Bogor. Sekolah Pasca sarjana. Institute Pertanian Bogor.

Wati I, Ida A. S. 2015. Penggunaan Rumput Laut (Eucheuma cottonii) Sebagai Pengganti Karagenan Dalam Pembuatan Jelly Drink Rosella (Kajian Konsentrasi Rumput Laut Dan Karagenan). Vol. 12, No. 1.

Yuliarti, E. S. 1999. Formulasi Bahan Penyusun dan Daya Awet Dodol Rumput Laut [Skripsi]. IPB. Bogor. 